\title{
The Correlation between Waist-to-Height Ratio (WHtR) and Second to Fourth Digit Ratio (2D:4D) with an Increase in Metabolic Syndrome Scores in Obese Adolescent Girls
}

\author{
Sophia Rose ${ }^{1}$, Fillah Fithra Dieny ${ }^{1,2^{*}}$, Nuryanto ${ }^{1,2}$, A. Fahmy Arif Tsani ${ }^{1,2}$
}

${ }^{1}$ Department of Nutrition, Faculty of Medicine, Universitas Diponegoro, Semarang, Central Java, INDONESIA ${ }^{2}$ Center of Nutrition Research, Faculty of Medicine, Universitas Diponegoro, Semarang, Central Java, INDONESIA

*Corresponding Author: fillahdieny@gmail.com

Citation: Rose S, Dieny FF, Nuryanto, Arif Tsani AF. The Correlation between Waist-to-Height Ratio (WHtR) and Second to Fourth Digit Ratio (2D:4D) with an Increase in Metabolic Syndrome Scores in Obese Adolescent Girls. Electron J Gen Med. 2020;17(3):em211. https://doi.org/10.29333/ejgm/7872

\section{ARTICLE INFO}

Received: 4 Feb. 2020

Accepted: 12 Mar. 2020

\section{ABSTRACT}

Purpose: The purpose of this study was to look at the correlation between waist-to-height ratio (WHtR) and second to fourth digit ratio (2D:4D) with an increase in metabolic syndrome scores in obese female adolescents.

Methodology: This research was founded by The Ministry of Research, Technology and Higher Education 2019. A cross-sectional study, which used simple random sampling technique when selecting subjects, involving 80 female university students aged $18-21$ years old at Universitas Diponegoro with waist circumference $>80 \mathrm{~cm}$. The data studied were components of the metabolic syndrome, weight, height, and index-ring finger length. Anthropometric profiles were obtained using direct measurement. Fasting blood glucose, triglycerides and HDL cholesterol were measured using enzymatic colorimetric techniques. Metabolic syndrome data was converted to metabolic syndrome score (cMetS). Data analysis using Rank Spearman and Pearson correlation test.

Results: High WHtR of 95\%, high 2D:4D of the right hand of $21.3 \%$ and left hand of 33.8\%. Most subjects had premetabolic syndrome (80\%) while the rest had metabolic syndrome. Bivariate test results showed that WHtR was positively correlated with cMetS, waist circumference, systolic and diastolic blood pressure. The right and left hand digit ratios did not correlate with cMetS nor with the components of the metabolic syndrome.

Applications/Originality/Value: This study contributes to anthropometric references to detect metabolic syndrome.

Keywords: waist-to-height ratio (WHtR), digit ratio (2D:4D), continuous value of metabolic syndrome (cMetS)

\section{INTRODUCTION}

Adolescence is a transition period from childhood into adulthood, because at this time there are biological, psychosocial, and cognitive changes which have a direct effect on nutritional status (1). The nutritional status of adolescents nowadays is not only focused on lack of nutrition, but also on over nutrition or obesity. Based on the results of Riskesdas in 2018 (is a descriptive cross sectional survey, that research to collect basic data and health indicators after 2013 that represent national, provincial and district/city regions), the prevalence of central obesity at the age of $\geq 15$ years has increased from $26.6 \%$ in 2013 to $31 \%$ in 2018 (2). Obesity is closely related to degenerative diseases. Degenerative diseases are chronic diseases with long duration and develop slowly. The type of degenerative diseases according to WHO is cardiovascular or coronary heart disease and stroke (3). The results of Riskesdas in 2018 show that the prevalences of stroke, diabetes mellitus, heart disease, and hypertension are higher in women than men (2). The effect from these conditions is the emergence of metabolic disease's risk which is often known as metabolic syndrome.

According to the International Diabetes Federation (IDF) 2006 metabolic syndrome is a group of heart diseases which have the most dangerous risk factors, such as diabetes mellitus, increased fasting blood glucose level, central obesity, high cholesterol level, and high blood pressure. It is estimated that around $20-25 \%$ of the adult population in the world have metabolic syndrome (4). Generally, metabolic syndrome is found on adults. However, recent studies have reported that there are metabolic syndrome which are found in adolescents. Based on research conducted at SMA Negeri 15 Semarang, it is stated that $68.4 \%$ of the subjects had metabolic syndrome and $31.6 \%$ from them had pre-metabolic syndrome (5).

Metabolic syndrome is usually diagnosed based on criteria, given that if someone who has 1-2 signs from the criteria being diagnosed with pre-metabolic syndrome while someone who has three or more signs is diagnosed with metabolic syndrome. Recent study can be assessed using the continuous value of metabolic syndrome (cMets) or the metabolic syndrome score proposed by the American Diabetic Association of Diabetes. The metabolic syndrome score is an assessment of all 
metabolic syndrome components which are converted to zscore (6). The advantages of using cMetS are: (1) reducing the dichotomization factor because cardiovascular disease is a progression from several metabolic syndrome components, (2) cMetS is more sensitive and there are less error occurred than when using categorical assessment of metabolic syndrome, (3) statistical power is higher when using cMetS (7). Research on children subjects showed that cMetS can be used to predict someone's metabolism $(6,8)$.

One component in the parameters of metabolic syndrome is central/abdominal obesity. Central obesity is the initial cause of metabolic syndrome due to impaired balance of adipocytokines which have been secreted. Central obesity is associated with increased blood pressure, serum triglycerides, decreased HDL, and glucose intolerance (9).

The parameters of central obesity markers in adolescents can be determined using Waist-to-Height Ratio (WHtR) whose results are stated to be more accurate than BMI (9). Measuring instruments used are microtoise (height measurement tool) and metline band (a measuring tool in the form of a measuring tape that can be rolled up) so they require more time when measuring. Waist-to-Height Ratio (WHtR) or the ratio of waist circumference to height is the indicator of central obesity and proposed as a better predictor for early risk of cardiovascular disease compared to BMI $(10,11)$. Studies on waist circumference have been shown to be closely associated with fat deposits in the abdomen (12). The distribution of abdominal adipose tissue (central obesity) in children and adults is positively correlated to metabolic syndrome components (13). Study with adult subjects showed that people who have the same waist circumference but with shorter height have a greater risk of getting metabolic syndrome than taller people (12). Thus WHtR can be used as an indicator of obesity in an individual.

Recently there was a report of an anthropometric measurement as an indicator in predicting cardiovascular disease which are faster than WHtR measurements, namely The Ratio of Second to Fourth Digit Ratio (2D:4D) (14). Finger lengths were measured using a digital caliper measuring to $0.001 \mathrm{~mm}$ (15). This method is faster than the WHtR measurement. The ratio of index finger and ring finger length (2D:4D) is an overview of a person's prenatal testosterone and estrogen levels. The ring finger is the fourth digit and the index finger is the second digit, both fingers are the most sensitive (13). Study about digit ratio began in 2 years old children, and possibly increased the formation of digit ratio since early of life. This study leads to the hypothesis that the number of digit ratio reflects embryo's exposure to testosterone and estrogen hormones which are formed since the end of the first trimester of fetal development and remains relatively stable throughout the life, which tend to develop certain diseases in the future $(14,16,17)$. This hypothesis has not been tested using experimental study (17). Digit ratio in women is proven to be higher than in men; it is associated with higher estrogen levels than testosterone and vice versa (13). Study on digit ratio showed good correlation with anthropometric measurements of adiposity (12). Other studies stated that digit ratio is directly associated with obesity and inversely associated with body muscle mass, which is considered as a risk factor in the future (18).

Research on digit ratio and WHtR in metabolic syndrome has not been done in Indonesia. Based on the magnitude of the problem that has been described previously, the purpose of this study was to analyze the correlation between waist-toheight ratio (WHtR) and second to fourth digit ratio (2D:4D) with an increase in metabolic syndrome scores in obese adolescent girls.

\section{METHODOLOGY}

The scope of this study was community's nutrition with a cross-sectional design. The subjects in this study were female university students who were 18-21 years old at Universitas Diponegoro, Semarang. The research began with nutrition screening at 10 metli faculties at Universitas Diponegoro by randomly selecting study programs at each faculty. Anthropometric measurements performed during screening were weight, height and waist circumference. This study obtained a total of 1260 female students at Universitas Diponegoro.

The inclusion criteria for the sample are women who were 18-21 years old; filled out informed consent; had waist circumference $>80 \mathrm{~cm}$; had intact fingers on both hands; did not take drugs that can affect blood pressure, cholesterol levels, and blood glucose levels; were willing to do fasting for at least 8 hours also did not smoking and/or consuming alcohol; were not in any state of illness or in the care of a doctor; were not doing intensive physical activity or training; were not pregnant and breastfeeding. The exclusion criterias were that the subject resigned from the study, the subject moved to a university and the subject died during the study. Based on inclusion criteria, this study obtained 215 subjects.

The sample selection method in this study used simple random sampling method and obtained 80 people. Data collected included general data about the subject's identity, anthropometric measurements such as body weight, height, waist circumference, index finger length and ring finger length using minimal clothing and blood sampling. Body weight was measured using a digital scale with an accuracy of $0.01 \mathrm{~kg}$. Nutritional status was based on Body Mass Index (BMI) and used category for Indonesians (19).

The independent variables in this study were waist circumference to height ratio (WHtR) and the index finger to ring finger length ratio (2D:4D). The waist circumference to height ratio (WHtR) using cut-off points for Asian people is $\geq 0.50$ (20). Subjects used minimal clothing in the anthropometric measurement process. Height was measured using a microtoise with an accuracy of $0.01 \mathrm{~cm}$ and during measurements, the subject didn't use any footwear and accessories on the head. Waist circumference was measured at the midpoint between the iliac crest and margin of costae (lower rib) using a metline band with a precision of $0.1 \mathrm{~cm}$ and when measuring, subjects used a thin clothings (11). Measurement of the digit ratio using digital calipers with a precision of $0.001 \mathrm{~mm}$. The subjects, hadn position were open with palm showing when doing the measurement. The length of the second finger (index finger) was the distance from the midpoint of the second metacarpophalangeal joint and the most distal point from the second finger, while the length of the fourth finger (ring finger) is from the midpoint of the fourth metacarpophalangeal joint to the most distal point of the fourth finger. After that, the length of the second and fourth fingers were divided to get the digit ratio results. The digit ratio limit in women used for the right hand and left hand are grouped as low if the ratio was $<1$ and high if it was $\geq 1.17$. While 
Table 1. Characteristic of Subject

\begin{tabular}{|c|c|c|c|}
\hline Variable & Min & Max & Mean \pm SD \\
\hline Age (years) & 18 & 21 & $19 \pm 0.8$ \\
\hline Weight (kg) & 52.3 & 103.6 & $70.95 \pm 11.2$ \\
\hline Heigh $(\mathrm{cm})$ & 100.5 & 1714 & $156.66 \pm 10.0$ \\
\hline WHtR (ratio) & 0.5 & 095 & $0.57 \pm 0.1$ \\
\hline Right Hand Digit Ratio (ratio) & 0.84 & 1.09 & $0.98 \pm 0.0$ \\
\hline Left Hand Digit Ratio (ratio) & 0.89 & 1.07 & $0.99 \pm 0.0$ \\
\hline \multicolumn{4}{|l|}{ Category of Metabolic Syndrome } \\
\hline Waist Circumference $(\mathrm{cm})$ & 81.2 & 114 & $88.93 \pm 6.5$ \\
\hline Systolic Blood Pressure (mmHg) & 87 & 144 & $110.14 \pm 11.3$ \\
\hline Diastolic Blood Pressure (mmHg) & 29 & 96 & $75.65 \pm 8.8$ \\
\hline HDL Cholesterol Levels (mg/dL) & 34 & 74 & $50.64 \pm 9.2$ \\
\hline Triglyceride Levels (mg/dL) & 43 & 248 & $10226 \pm 38.6$ \\
\hline Fasting Blood Glucose Levels (mg/dL) & 68 & 206 & $89.18 \pm 15.5$ \\
\hline cMetS (score) & -6.16 & 9.68 & $000 \pm 2.8$ \\
\hline
\end{tabular}

the dependent variables in this study were metabolic syndrome components (waist circumference, blood pressure, fasting blood sugar levels, triglyceride levels and HDL cholesterol level which later would be converted into metabolic syndrome score (cMetS). The cMetS limit/threshold value in this study was $>2.21$ (6).

Blood sampling was in collaboration with the Sarana Medika laboratory. The measured blood profiles included fasting blood sugar levels, triglyceride levels, and levels for women using enzymatic colorimetric techniques. While blood pressure was measured using digital tensimeter with the brand named "Omron" and was conducted by trained students and measured twice. This study used the metabolic syndrome guidelines according to the National Cholesterol Education Program-Adult Treatment Panel (NCEP-ATP III) 2005 which was often used in many studies in Indonesia, there are 5 markers, in assessing metabolic syndrome, if someone meets 3 of the 5 agreed criterias, such as: (1) central obesity (women's waist circumference $\geq 80 \mathrm{~cm}$ ); (2) systolic blood pressure $\geq 130 \mathrm{mmHg}$ or diastolic blood pressure $\geq 85 \mathrm{mmHg}$; (3) triglyceride levels $\geq 150 \mathrm{mg} / \mathrm{dL}$; (4) HDL cholesterol levels $<50 \mathrm{mg} / \mathrm{dL}$ for women; (5) fasting blood glucose level $\geq 110 \mathrm{mg} / \mathrm{dL}$ (21).

This study changed the parameters of metabolic syndrome into metabolic syndrome score (cMetS) by changing them into z-score. CMetS measurement was done in several stages, which is: (1) measuring all metabolic syndrome parameters including waist circumference, blood pressure, HDL cholesterol levels, triglyceride levels and fasting blood glucose levels; (2) standardizing by changing all the results of metabolic syndrome parameters in Z-score form; (3) specifically blood pressure results must be changed to Mean Artierial Blood Pressure (MAP) form first; (4) the HDL cholesterol levels standardization results are inversely proportional to the metabolic risk thus the HDL Z-score was multiplied by (-1); (5) after getting all the Z-scores, the researcher obtained the cMetS by adding up all the Z-scores from the waist circumference, HDL cholesterol levels, triglyceride levels and fasting blood glucose levels also MAP; (6) the cMetS score $\geq 2.21$ indicated metabolic syndrome $(22,23)$. The MAP calculation follows the two measurement parameters Systolic blood pressure and Diastolic blood pressure.

$$
\begin{gathered}
\text { MAP }=\{[(\text { Systolic blood pressure }- \text { Diastolic blood pressure }) \\
: 3]+ \text { Diastolic blood pressure }\}
\end{gathered}
$$

Univariate analysis was performed to describe the characteristics of the subject, the variables studied were WHtR and digit ratio as independent variables and cMetS as the dependent variable. Data normality test used KolmogorovSmirnov. Bivariate analysis used the Spearman Rank test if data didn't normally distributed and Pearson test for normally distributed data.

\section{RESULTS}

\section{Subjects Characteristic}

Based on the screening results of 1260 female students in 10 faculties at Universitas Diponegoro. Research subjects whom met the inclusion criteria were 215 female students and after that 80 female students were randomly selected to be samples in this study. The results of research on Universitas Diponegoro student, where they obtained the characteristics of the research variables including general data about the subjects, anthropometric data, and metabolic syndrome component data, were shown in Table 1.

The mean age in this study was shown in Table 1, which was 19 years with the mean weight of the subject was $70.95 \pm$ 11.2 and the average height of the subject was $156.66 \pm 10.0$. The median WHtR of the subjects was $0.57 \pm 0.1$, while the median digit ratio of the right hand was $0.98 \pm 0.04$ and the left hand was $0.99 \pm 0.04$. The metabolic syndrome components consisted of waist circumference, blood pressure, HDL cholesterol levels, triglyceride levels, and sometimes fasting blood glucose levels. Waist circumference had an average of $88.93 \pm 6.53 \mathrm{~cm}$, systolic blood pressure's mean of $110 \mathrm{mmHg}$, diastolic blood pressure's mean of $76.65 \mathrm{mmHg}$, HDL cholesterol levels' mean of $50.64 \mathrm{mg} / \mathrm{dL}$, triglyceride levels' mean of $102.26 \mathrm{mg} / \mathrm{dL}$, and sometimes also tested fasting blood glucose levels with average of $89.18 \mathrm{mg} / \mathrm{dL}$. While cMetS mean was 0.00 .

The subjects in this study were 18-21 years old. Table 2 showed that the characteristic of the subjects in this study, which was dominated by nutritional status based on BMI, was obesity, with category I obesity was $40 \%$ and category II obesity was $36.3 \%$. In addition, there were $12.5 \%$ of the subjects who had normal nutritional status. Based on anthropometric profile using WHtR, there were $95 \%$ which were classified as high. While the anthropometric profile using the right hand digit ratio was $21.3 \%$ and the left hand was $33.8 \%$ which classified in the high category. Subjects who had 1-2 metabolic syndrome markers were $80 \%$ while $20 \%$ had $\geq 3$ metabolic syndrome markers. Subjects with high cMetS were $20 \%$. 
Table 2. Frequency distribusi of Waist Height-to-Ratio (WHtR), Digit Ratio (2D:4D) and Metabolic Syndrome

\begin{tabular}{|c|c|c|}
\hline Variable & $\mathbf{n}$ & $\%$ \\
\hline \multicolumn{3}{|l|}{ Nutritional Status was based on BMI } \\
\hline Normal $(18,5-22,9 \mathrm{~kg} / \mathrm{m} 2)$ & 10 & 12.5 \\
\hline Overweight $(23,0-24,9 \mathrm{~kg} / \mathrm{m} 2)$ & 9 & 11.3 \\
\hline Obesity I $(25,0-29,9$ kg/m2) & 32 & 40 \\
\hline Obesity II ( $\geq 30 \mathrm{~kg} / \mathrm{m} 2)$ & 29 & 36.3 \\
\hline \multicolumn{3}{|l|}{ WHtR } \\
\hline Normal $(<0,5)$ & 4 & 5 \\
\hline $\operatorname{High}(\geq 0,5)$ & 76 & 95 \\
\hline \multicolumn{3}{|l|}{ Right Hand Digit Ratio } \\
\hline $\operatorname{Low}(<1.00)$ & 63 & 78.8 \\
\hline High $(\geq 1.00)$ & 17 & 21.3 \\
\hline \multicolumn{3}{|l|}{ Left Hand Digit Ratio } \\
\hline $\operatorname{Low}(<1.00)$ & 53 & 663 \\
\hline High $(\geq 1.00)$ & 27 & 33.8 \\
\hline \multicolumn{3}{|l|}{ Waist Circumference } \\
\hline Normal $(<80 \mathrm{~cm})$ & 0 & 0 \\
\hline Central Obesity $(\geq 80 \mathrm{~cm})$ & 80 & 100 \\
\hline \multicolumn{3}{|l|}{ Systolic Blood Pressure } \\
\hline Normal (<130 mmHg) & 78 & 97.5 \\
\hline High $(\geq 130 \mathrm{mmHg})$ & 2 & 2.5 \\
\hline \multicolumn{3}{|l|}{ Diastolic Blood Pressure } \\
\hline Normal $(<85 \mathrm{mmHg})$ & 76 & 95 \\
\hline High ( $\geq 85 \mathrm{mmHg}$.) & 4 & 5 \\
\hline \multicolumn{3}{|l|}{ HDL Cholesterol Levels } \\
\hline Normal ( $\geq 50 \mathrm{mg} / \mathrm{dL})$ & 44 & 55 \\
\hline Low (<50 mg/dL) & 36 & 45 \\
\hline \multicolumn{3}{|l|}{ Triglyceride Levels } \\
\hline Normal (<150 mg/dL) & 71 & 88.8 \\
\hline High ( $\geq 150 \mathrm{mg} / \mathrm{dL})$ & 9 & 11.3 \\
\hline \multicolumn{3}{|l|}{ Fasting Blood Glucose Levels } \\
\hline Normal (<110 mg/dL) & 77 & 96.3 \\
\hline High $(\geq 110 \mathrm{mg} / \mathrm{dL})$ & 3 & 3.8 \\
\hline \multicolumn{3}{|l|}{ Metabolic Syndrome Status } \\
\hline Pre-Metabolic Syndrome (1-2) & 64 & 80 \\
\hline Metabolic Syndrome $(\geq 3)$ & 16 & 20 \\
\hline \multicolumn{3}{|l|}{ cMetS } \\
\hline Normal $(<2,21)$ & 64 & 80 \\
\hline High $(\geq 2,21)$ & 16 & 20 \\
\hline
\end{tabular}

The Correlation between Waist Height to Ratio (WHtR) and Digit Ratio (2D:4D) with Metabolic Syndrome Score (cMetS) in Obese Adolescent Girls

Based on the research results and calculations which have been done, it was obtained anthropometric profile measurement data of waist circumference to body height ratio (WHtR) and index finger length to ring finger length ratio (2D:4D) with metabolic syndrome scores (cMetS) and metabolic syndrome components were shown in Table 3.

There was an correlation if $p<0.05$ and stated to be positively related if $r$ value was positive. Table 3 showed that
WHtR was statistically related to cMets. The higher the WHtR value, the greater the metabolic syndrome scores (cMetS). In addition, WHtR was also positively related to 2 metabolic syndrom markers, which was waist circumference, systolic blood pressure, diastolic blood pressure. While the right hand and left hand digit ratio variables showed no significant correlation with the metabolic syndrome score and the metabolic syndrome components in obese adolescent girls ( $p$ $>0.05)$.

\section{DISCUSSION}

\section{Research Subjects Characteristics}

Based on the research subjects' characteristics in Universitas Diponegoro Semarang students who were 18-21 years, the average age was 19 years. The age range was classified in the category of late adolescents (17-21 years) according to the World Health Organization (WHO) in which a transition from adolescence to early adulthood happens (19). Late adolescents are marked by the development of personal identity and moral beliefs of the individuals. The ability to think for future goals can been seen, such as understanding the future consequences associated with current behavior and even ability to think about having children or getting pregnant. Students are included in the category of late adolesence who start living independently. The number of activities done by university students which force them to skip meals is a common thing. Most of the late adolescents choose to eat fast food or buy food at a food stall because it is more practical. Eating snacks can also be their solution. The average snack size is more or less the same, but the amont of snacks consumed increases. This contributes to increased calories intake that contains a lot of fat and is low in fiber (1). Hence, irregular eating habits in adolescents need more concern. Based on research conducted in Nepal in adult subjects, low intake of monounsaturated fat (MUFA), polyunsaturated fat (PUFA) and polyunsaturated fatty acids caused an increase in the prevalence of obesity and metabolic syndrome. Because nowadays healthy diet is replaced by high fat and calories food (24).

Late adolescence, especially in women, has higher risk of metabolic syndrome because adipose tissue in the lower body (hips and thighs) is related to fat distribution (25). In addition, it will have an impact on the future and can pose a risk to the offspring. Metabolic syndrome is determined based on the interaction of various genetic and environmental factors. Genetic factors in the family such as obesity, hypertension and diabetes are at risk for the occurrence of metabolic syndrome (26). Since 2007, Genome Wide Association Studies (GWAS) have identified about 88 loci which was associated with the risk

Table 3. Correlation between Waist Height-to-Ratio (WHtR) and Digit Ratio (2D:4D) with Metabolic Syndrome Score (cMetS)

\begin{tabular}{|c|c|c|c|c|c|c|}
\hline \multirow{2}{*}{ Variable } & \multicolumn{2}{|c|}{ WHtR } & \multicolumn{2}{|c|}{ Right Hand 2D:4D } & \multicolumn{2}{|c|}{ Left Hand 2D:4D } \\
\hline & $r$ & $\mathbf{p}$ & $r$ & $\mathbf{p}$ & $r$ & $\mathbf{p}$ \\
\hline cMetS & $0.53^{\mathrm{a}}$ & $0.000^{\mathrm{a}}$ & $0.14^{\mathrm{a}}$ & $0.222^{\mathrm{a}}$ & $0.03^{b}$ & $0.824^{b}$ \\
\hline WC & $0.83^{a}$ & $0.000^{\mathrm{a}}$ & $0.08^{\mathrm{a}}$ & $0.498^{a}$ & $-0.07^{\mathrm{a}}$ & $0.556^{\mathrm{a}}$ \\
\hline Systolic BP & $0.33^{\mathrm{a}}$ & $0.003^{\mathrm{a}}$ & $0.06^{\mathrm{a}}$ & $0.598^{\mathrm{a}}$ & $0.07^{\mathrm{b}}$ & $0.565^{b}$ \\
\hline Diastolic BP & $0.4^{\mathrm{a}}$ & $0.000^{\mathrm{a}}$ & $0.11^{a}$ & $0.332^{\mathrm{a}}$ & $0.06^{\mathrm{a}}$ & $0.581^{a}$ \\
\hline HDL Cholesterol & $0.03^{a}$ & $0.794^{a}$ & $0.01^{a}$ & $0.908^{a}$ & $0.10^{\mathrm{b}}$ & $0.360^{b}$ \\
\hline Triglyceride & $0.17^{a}$ & $0.132^{a}$ & $0.13^{a}$ & $0.261^{\mathrm{a}}$ & $0.16^{a}$ & $0.154^{\mathrm{a}}$ \\
\hline Fasting Blood Glucose & $0.20^{\mathrm{a}}$ & $0.073^{\mathrm{a}}$ & $0.02^{\mathrm{a}}$ & $0.837^{\mathrm{a}}$ & $0.04^{\mathrm{a}}$ & $0.707^{a}$ \\
\hline
\end{tabular}

a: Rank Spearman, b: Pearson 
of developing type 2 diabetes mellitus. Most loci were associated with insulin secretion and pancreatic beta cell function, thereby causing insulin resistance which was associated with obesity (27).

Other subject characteristics in terms of BMI showed that most of the subjects had obesity in nutritional status, with obesity I was found at $40 \%$ of the subjects and obesity II at $36.3 \%$. The overweight and obesity in BMI category are related to the metabolic syndrome components, which is in line with research in Syria on the adolescent subjects who were 18-19 years (28). There are various medical and psychosocial complications related to overweight and obesity among adolescents such as hypertension, dyslipidemia, insulin resistance, type 2 diabetes mellitus, sleep disorders and other respiratory disorders (1).

The prevalence of metabolic syndrome in this study, using the NCEP-ATP III criteria, found pre-metabolic syndrome at $80 \%$ of the subjects and metabolic syndrome at $20 \%$. Based on Herningtyas and Ng's research in Indonesia on subjects obtained through the Family Life Survey Wave 4 (IFLS4) spread in 20 provinces in Indonesia, it was stated that the prevalence of metabolic syndrome in Indonesia is high (moderate). Premetabolic syndrome with 2 markers was at $39.45 \%$. The majority of subjects who have metabolic syndrome in Java had reached $15.16-37.5 \%$ (29). Whereas, in this study when we looked at the metabolic syndrome score, we obtained a prevalence of $20 \%$ which is classified in the high category. In line with the research of Pratiwi et all who used secondary data from the Basic Health Research (Riskesdas) 2013 in 15-24 years adolescents showed that the prevalence of cMets in adolescents was $19.89 \%$ (6).

\section{The Correlation between WHtR with Metabolic Syndrome}

The first anthropometric profile is the waist circumference to height ratio (WHtR), which $95 \%$ of subjects have a high WHtR status. The WHtR value used in Asian societies is $\geq 0.50$ (20). In a study of University of Baghdad students, aged 19-22 years, found that $30.3 \%$ of the subjects were classified as central obesity based on WHtR. Whereas research on students in 8 ASEAN countries found that $11.9 \%$ of female students had high WHtR (30). Other research conducted on students of SMAN 2 Ungaran, aged 14-18 years, showed a higher prevalence among female students than men (31). The high prevalence of WHtR in adolescents in Indonesia shows that anthropometric measurements of WHtR can already be done for early adolescents.

Adolescents are still undergoing growth process so WHtR can give an overview about cardiovascular disease. Most scientists recommend WHtR in over nutrition screening for adolescents which can also function as a risk predictor of noncommunicable diseases such as cardiovascular disease, because WHtR can describe body fat percentage and adipose tissue/visceral fat mass $(31,32)$. Some studies also reported that WHtR is a better indicator than Body Mass Index (BMI) and waist circumference to identify obesity, because it affects changes in height, age and gender differences $(13,33)$. However, when compared between the two sexes it is possible to experience bias due to height differences in women and men $(13,31,33)$. In addition, WHtR can be used to identify risk factors for cardiovascular disease such as diabetes mellitus and metabolic syndrome (33). Waist circumference and BMI can also be used as alternatives in detecting cardiovascular disease, but WHtR has higher sensitivity.
Waist circumference is one of the components in determining WHtR because it can describe obesity in adolescent. Obesity is defined as excess body fat mass which become a risk for cardiovascular disease (34). Factors causing obesity in adolescents are multifactorial. Increased consumption of fast food, rarely doing physical activity, genetic factors, advertisement influence, psychological factors, socioeconomic status, diet, age, and gender are factors which contribute to changes in energy balance that leads to obesity (35). There are many studies which related to cardiovascular disease, with research subjects not only on adults and the elderly but also in children and adolescents.

Obesity is associated with increased risk for type 2 diabetes mellitus (T2DM) and cardiovascular disease (CVD). Accumulation of excess fat in the abdominal area is associated with cardiometabolic risk. Although most previous studies used indirect measurements, such as thickness of the subcutaneous fat, underwater weight measurement, waist circumference (WC), waist to hip ratio (WHR), waist to height ratio (WHtR) to estimate the distribution of belly fat (36).

Central (abdominal) obesity is a major risk factor for systemic inflammation, hyperlipidemia, insulin resistance, and cardiovascular disease. However, central obesity does not always occur in individuals with high BMI. Several studies in 1981 stated that metabolic obesity was caused by the accumulation of excess visceral fat. Visceral obesity plays a role in proinflammation associated with metabolic syndrome. Many studies suggest that changes in body composition, especially the reduction in abdominal fat deposits, are more important than overall weight reduction or BMI in dealing with metabolic syndrome, because central obesity is a marker of dysfunctional adipose tissue (37).

One component of metabolic syndrome is waist circumference which is also a component in determining WHtR and also used to describe central obesity in a person. This study showed a correlation between WHtR with cMetS and WHtR with waist circumference, systolic blood pressure, diastolic blood pressure. The correlation between these two is positively correlated which means that the greater the WHtR, the higher the risk of metabolic syndrome. While the other metabolic syndrome components (HDL cholesterol, triglycerides, fasting blood sugar) in this study have no correlation.

A person with hypertension are usually associated with cardiovascular metabolic risk factors (38). The incidence of metabolic syndrome shows increased risk of cardiovascular morbidity and mortality as hypertension is associated with preclinical cardiovascular and renal changes, such as left ventricular hypertrophy, early carotid atherosclerosis, aortic elasticity disorders, hypertensive retinopathy and microalbuminuria (39). Hypertension can also be found in someone who is obese due to insulin resistance and impaired endothelial function of blood vessels (40).

Research that had been done before showed that the metabolic syndrome score (cMetS) was better in showing the status of metabolic syndrome than using categorical assessment of metabolic syndrome. Continuous Metabolic Syndrome (cMetS) or metabolic syndrome score is an assessment for metabolic syndrome including measurement of obesity, fat, glucose/insuli, blood pressure and other components including smoking and physical activity which will be converted into Z-score (41). Adolescents who are 15-24 years in Indonesia have cMetS of 2.21 because if it is more than that then they can be diagnosed with metabolic syndrome (6). 


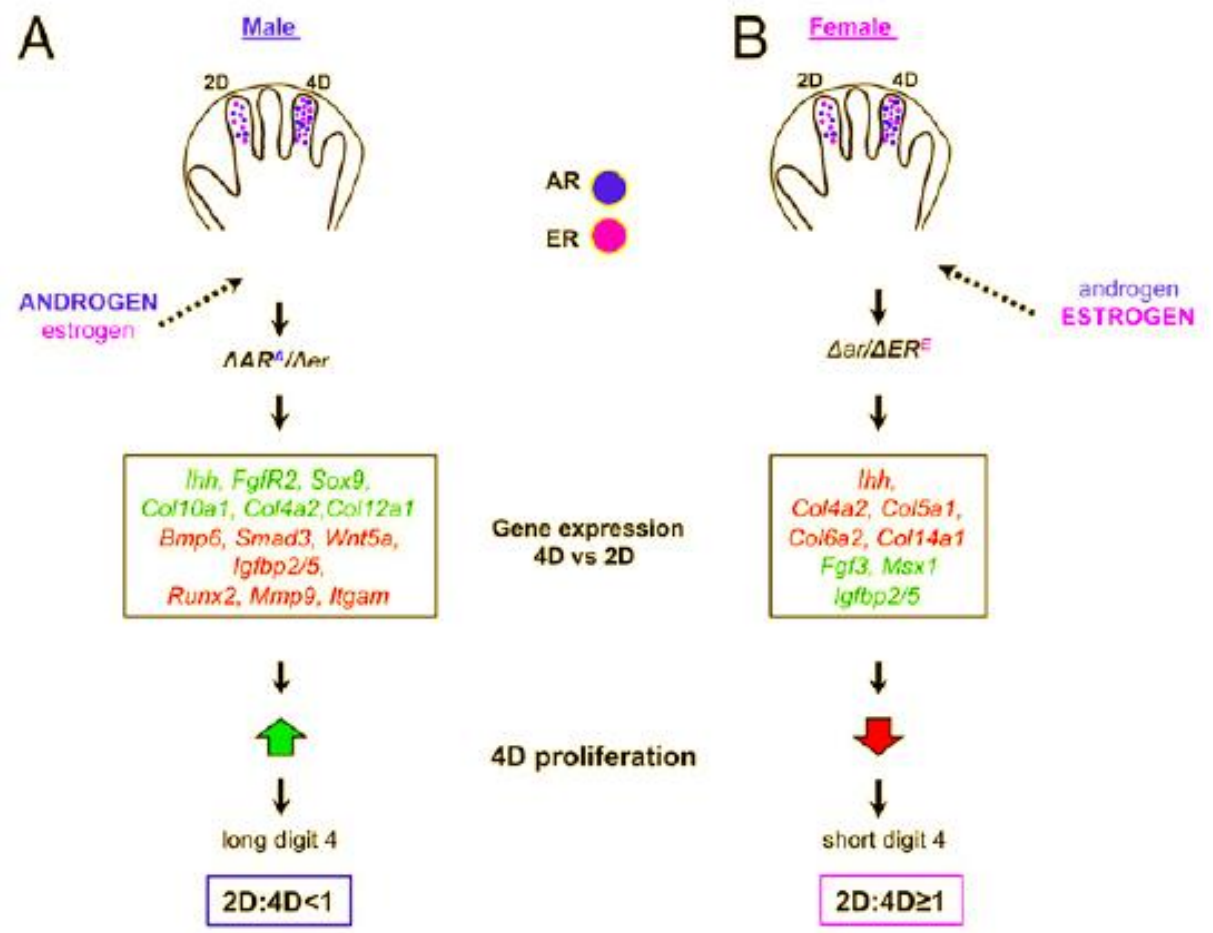

Figure 1. Genes that have roles in the formation of digit ratio

\section{The Correlation between Digit Ratio with Metabolic Syndrome}

The prevalence in this study found that right hand digit ratio of $21.3 \%$ was in the high category while $78.8 \%$ was in the low category. While the left hand digit ratio was $33.8 \%$ in the high category and $66.3 \%$ in the low category. Research conducted by Kumar et all on the students in Malaysia as subjects found high digit ratio prevalence of 55\% (16). While previous studies conducted in Indonesia on YARSI University students in Central Jakarta also found a high digit ratio prevalence of $45.82 \%$ (14).

The length of the second and fourth fingers reflects the hormones testosterone and estrogen levels during the prenatal period (42). Women tend to have 2D and 4D that have similar length rather than men whose $2 \mathrm{D}$ tend to be shorter than their $4 \mathrm{D}$, so most of the digit ratios in men are $<1$ and $\geq 1$ in women $(17,43)$. Men with lower digit ratios have higher testosterone levels than estrogen and vice versa in women. In addition, a low digit ratio radiographically is associated with an increased risk of knee osteoarthritis (OA) and/or OA hips as well as having higher risk for myocardial infarction $(14,42)$. The distribution of the body's adipose tissue is affected by sexual hormone levels in men and women. Estrogen levels increase adipose tissue around a woman's hips and thighs, while an increase in testosterone in men can increase adipose tissue around the abdomen, shoulders and neck (42). Research on digit ratios as a reflection of prenatal hormone exposure was shown in studies conducted on mouse models because they had digits, like humans, which indicated that the digit ratio was determined by the hormonal environment at the fingers' cartilage development time which could be used to interpret the basis of sexual, behavior and disease development (17).

The value of digit ratio is influenced by the balance of fetal estrogen and testosterone. Both of these hormones affect the fingers growth and development in the embryological period.
Research conducted at the University of Florida reported that activity of fetal estrogen and testosterone was assessed by the expression of Androgen Receptor (AR) and Estrogen Receptor alpha (ER-alpha) which both were higher on the 4th finger than the 2nd finger (17).

Estrogen function is influenced by Estrogen Receptor (ER) which is spread in various types of blood vessels, the function of ER itself is to assist the transcription process. Estrogen has two receptors, ER-alpha and ER-beta which have opposite metabolic functions. Generally ER-alpha leads to metabolic syndrome phenotypes such as impaired glucose homeostasis and inflammation in the experimental mouse, but it also has function to decrease adiposity while ER-beta accelerates adiposity. The loss of ER-alpha function in adipose tissue specifically causes adipose tissue dysfunction which can cause inflammation and fibrosis. Therefore both ERs are considered important in the adipose tissue function and metabolic phenotypes (44).

Androgen and estrogen signaling control digit development by regulating the growth of cartilage cells in the finger over and over. The basic development in digit ratios in sexual way is shown in Figure 1. Blue dots are AR and pink dots are ERs found in male and female embryo digits, with higher numbers are found in 4D. (A) In men, digits are exposed to more androgens than estrogen which results in the binding and activation of ARA. High AR and low ER activity in men leads to gene expression profiles in $4 D$ relative to $2 D$ with the green gene marked with names higher in $4 D$ and red genes higher in $2 \mathrm{D}$. As the results the $4 \mathrm{D}$ extension leads to a lower digit ratio. (B) In women, digits are more exposed to estrogen rather than androgen which lead to binding and activation of ERE. High or low ER activity causes the different (opposite) changes in the gene expression profiles in $4 \mathrm{D}$ relative to $2 \mathrm{D}$, marked by name of the green genes and red genes which are shown in Figure 1. Higher level of active ER decrease the growth of cartilage cells 
called chondrocytes continuously. Thus reducing growth in 4D which results in higher ratio digit (17).

Prenatal androgen level as determinant for digit ratios has been proven in the development of the cardiovascular system. Because it is associated with estrogen receptors in humans which leads to the development of ring fingers which are shorter than the index finger. Individuals who have lower 2D than 4D tend to have a well-developed cardiovascular system and normal cardiovascular function, and vice versa (15).

The results of this study indicated that there was no relationship between the digit ratio of the right and left hand with cMetS or metabolic syndrome components. Similar results were also found in studies conducted by Yildiz et all. with women aged over 18 years who were visiting Turkish clinics (45). Other studies with similar results conducted by Swani et al on female subjects aged 17-35 years showed no correlation between digit ratio with waist circumference, neck circumference, BMI, and hip waist circumference ratio where waist circumference is one of the metabolic syndrome components (46). Besides that, the digit ratio is usually used for research in finding relation between physiological and psychological conditions including fertility; athletic ability; gender-related disease; social behavior; sexual orientation (17). Several conditions such as autism, depression, congenital adrenal hyperplasia, polycystic ovary syndrome (15). Based on several digit ratio studies which related to cardiometabolic disease were using more than 1000 subjects, whereas in this study the subjects were only 80 so that the digit ratio indicator still could not describe a person's metabolic status. This study also required subjects with various nutritional status groups.

\section{CONCLUSIONS}

There was a positive and significant correlation between the waist circumference to height ratio (WHtR) with the metabolic syndrome score (cMetS). In addition, WHtR was also correlated with 2 components of metabolic syndrome, namely waist circumference and blood pressure. Digit ratio was not related to metabolic syndrome score (cMetS).

\section{ACKNOWLEDGEMENTS}

Thanks to Universitas Diponegoro and all subjects in all Faculties involved. This research was funded by the "Kementrian Ristekdikti State Minister of Research and Technology 2019."

\section{Ethics Clearance}

This study received permission from the Health Research Ethics Commission with No.373/EC/KEPK/FK UNDIP/VIII/2019.

\section{Suggestion}

Future studies will require a large amount of family and subject history data from different groups of nutritional status. WHtR indicators are significant for cMetS, but faster and practical measurements are needed for future research.

\section{REFERENCES}

1. Stang J. Adolescent Nutrition: Conditions and Interventions. In JE Brown (Ed.), Nutrition Through the Life Cycle (4th ed.). USA: Cengage Learning. 2011.

2. Badan Penelitian dan Pengembangan Kesehatan. Hasil Utama RISKESDAS 2018. Jakarta: Kementrian Kesehatan RI. 2018.

3. Sari K. Pengetahuan Gizi terkait Penyakit Degeneratif, Pola Konsumsi dan Aktivitas Fisik Mahasiswa IPB. Bogor: Institut Pertanian Bogor. 2015.

4. Emile A. The IDF Consensus Worldwide Definition of the Metabolic Shyndrome. Brussel, Belgium: International Diabetes Federation. 2006.

5. Dieny FF, Widyastuti N, Fitranti DY. Sindrom metabolik pada remaja obes: prevalensi dan hubungannya dengan kualitas diet. Jurnal Gizi Klinik Indonesia, 2015;12(1):1. https://doi.org/10.22146/ijcn.22830

6. Pratiwi ZA, Hasanbasri M, Huriyati E. Penentuan Titik Potong Skor Sindroma Metabolik Remaja dan Penilaian Validitas Diagnostik Parameter Antropometri: Analisis Riskesdas 2013. Jurnal Gizi Klinik Indonesia, 2017;14(2). Available at: https://jurnal.ugm.ac.id/jgki\%0APenentuan

7. Okosun I, Lyn R, David-Smith M, Eriksen M, Seale P. Validity of a Continuous Metabolic Risk Score as an Index for Modeling Metabolic Syndrome in Adolescents. AEP, 2010;10(11):843-51. https://doi.org/10.1016/j.annepidem. 2010.08.001 PMid:20933191

8. Shi P, et al. Continuous Metabolic Syndrome Scores for Children Using Salivary Biomarkers. Journal Pone. 2015. https://doi.org/10.1371/journal.pone.0138979 PMid:26418011 PMCid:PMC4587796

9. Saraswati AT, Sulchan M. Audina Tyas Saraswati, M Sulchan. Journal of Nutrition College, 2016;5(5):192-7.

10. Ashwell M, Gibson S. Waist-to-Height Ratio as An Indicator of 'Early Health Risk': Simpler and More Predictive Than Using A "Matrix" Based on BMI and Waist Circumference. BMJ Open, VI. 2016. https://doi.org/10.1136/bmjopen2015-010159 PMid:26975935 PMCid:PMC4800150

11. Yang $\mathrm{H}$, et al. Waist-to-Height Ratio is Better Than Body Mass Index and Waist Circumference as A Screening Criterion for Metabolic Syndrome in Han Chinese Adults. Medicine, 2017;XXXVI(96):1-8. https://doi.org/10.1097/MD. 0000000000008192 PMid:28953680 PMCid:PMC5626323

12. Zhou D, et al. Waist-to-Height Ratio: A Simple, effective and Practical Screening Tool for Childhood Obesity and Metabolic Syndrome. Preventive Medicine, 2014;67:35-40. https://doi.org/10.3934/publichealth.2017.3.301 PMid:29546219 PMCid:PMC5690456

13. Rodea-Montero ER, Evia-Viscarra ML, Apolinar-Jiménez E. Waist-to-height ratio is a better anthropometric index than waist circumference and BMI in predicting metabolic syndrome among obese mexican adolescents. International Journal of Endocrinology, 2014. https://doi.org/10.1155/2014/195407 PMid:25574166 PMCid:PMC4276350

14. Endang Purwaningsih MP. Insidensi panjang jari telunjuk terhadap jari manis (rasio 2D: 4D) pada mahasiswa Fakultas Kedokteran Universitas YARSI Angkatan 20132014. YARSI Medical Journal, 2016;24(1):001-008. https://doi.org/10.33476/JKY.V24I1.134 
15. Asuku AY, et al. Relationship of Second-to-Fourth Digit Ratio with Metabolic Syndrome Indices and Serum Biomarkers in Hausa ethnic group of Kano, Nigeria. Journal of Experimental and Clinical Anatomy, 2018;XVI(2):103-10. https://doi.org/10.4103/jeca.jeca_24_17

16. Kumar N, Sallehuddin MA, Syed SMFB, Idris MH, et al. The Ratio of Second to Fourth Digit Length (2D:4D) and Heart Disease. Bangladesh Journal of Medical Science, 2016;15(4):529. https://doi.org/10.3329/bjms.v15i4.23958

17. Zheng Z, Cohn M. Developmental Basis of Sexually Dimorphic Digit Ratios. PNAS, 2011;108(39). https://doi.org/10.1073/pnas.1108312108 PMid:21896736 PMCid:PMC3182741

18. Kitlesi K. Relationship Between Second to Fourth Digit Ratios and Obesity, Muscle Mass, 2-5. https://doi.org/10.4328/JCAM.3846

19. Susetyowati. Gizi Remaja. In Hardinsyah \& D. N. Supariasa (Eds.), Ilmu Gizi:Teori dan Aplikasi (1st ed., pp. 160-168). Jakarta: Penerbit Buku Kedokteran EGC. 2016.

20. Zhang Y, Wang Z, Chu Z, Zhao J. Profiles of Body Mass Index and The Nutritional Status among Children and Adolescents Categorized by Waist-to-Height Ratio Cut Offs. International Journal of Cardiology, 2016;223:529-33. https://doi.org/10.1016/j.ijcard.2016.07.303 PMid:27552573

21. Soewondo P, Purnamasari D, Oemardi M, Waspadji S. Prevalence of Metabolic Syndrome Using NCEP / ATP III Criteria in Jakarta, Indonesia: The Jakarta Primar. Dwipayana MP, Suastika K, Saraswati I, Gotera W, Budhiarta A, Sutanegara, et al. Prevalensi Sindroma Metabolik Pada Populasi Penduduk Bali, Indone, 2006:199203.

22. Eisenmann JC, et al. Construct Validity of A Continuous Metabolic Syndrome Score in Children. Diabetology \& Metabolic Syndrome, 2010;2(8). https://doi.org/10.1186/ 1758-5996-2-8

23. Okosun I, et al. Continuous Metabolic Syndrome Risk Score, Body Mass Index Percentile, and Leisure Time Physical Activity in American Children. The Journal of Clinical Hypertension, 2010;12(8). https://doi.org/10.1111/j.17517176.2010.00338.x PMid:20695944

24. Sharma SK, et al. Prevalence of Hypertension, Obesity, Diabetes, and Metabolic Syndrome in Nepal. International Journal of Hypertension, 2011:1-9. https://doi.org/10.4061/ 2011/821971 PMid:21629873 PMCid:PMC3095978

25. Pradhan AD. Sex differences in the metabolic syndrome: Implications for cardiovascular health in women. Clinical Chemistry, 2014;60(1):44-52. https://doi.org/10.1373/ clinchem.2013.202549 PMid:24255079

26. Varanasi VK. Metabolic Syndrome: The Genetic Aspect. Endocrinology \& Metabolic Syndrome, 2011;01(S1):1-2. https://doi.org/10.4172/2161-1017.s1-e001

27. Brown AE, Walker M. Genetics of Insulin Resistance and the Metabolic Syndrome. Curr Cardiol Rep, 2016;18(75). https://doi.org/10.1007/s11886-016-0755-4 PMid:27312935 PMCid:PMC4911377

28. Al-Bachir M, Bakir MA. Predictive Value of Body Mass Index to Metabolic Syndrome Risk Factors in Syrian Adolescents. Journal of Medical Case Report, 2017;11(170):1-7. https://doi.org/10.1186/s13256-017-1315-2 PMid:28646923 PMCid:PMC5483316
29. Herningtyas EH, Sheng T. Prevalence and Distribution of Metabolic Syndrome and Uts Components Among Provinces and Ethnic Groups in Indonesia. BMC Public Health, 2019;19(377):1-12. https://doi.org/10.1186/s12889019-6711-7 PMid:30943932 PMCid:PMC6448251

30. Peltzer K, Pengpid S. The Association of Dietary Behaviors and Physical Activity Levels with General and Central Obesity among ASEAN University Students. AIMS Public Health, 2017;4(3):301-13. https://doi.org/10.3934/public health.2017.3.301 PMid:29546219 PMCid:PMC5690456

31. Mulyasari I, Pontang GS. Waist Circumference and Waist-toHeight Ratio as Indicators for Excess Adiposity in Indonesian Adolescents. J. Gizi Pangan, 2018;13(3):131-6. https://doi.org/10.25182/jgp.2018.13.3.131-136

32. Nuaman BN, Khalil NS, Kamal W. Waist-to-Height Ratio as an Index of Central Obesity: its association with Life-Style Characteristics. Diyala Journal of Medicine, 2017;12(1):7583.

33. Mirzaei M, Khajeh M. Comparison of anthropometric indices (body mass index, waist circumference, waist to hip ratio and waist to height ratio) in predicting risk of type II diabetes in the population of Yazd, Iran. Diabetes and Metabolic Syndrome: Clinical Research and Reviews, 2018;12(5):677-82. https://doi.org/10.1016/j.dsx.2018.04. 026 PMid:29680518

34. Warren CL. Adolescent obesity. School Health Review, 1972;3(3):19-20. https://doi.org/10.1080/00366579.1972. 10612649

35. Kurdanti W, Suryani I, Syamsiatun NH, Siwi LP, Adityanti MM, Mustikaningsih D, Sholihah KI. Faktor-faktor yang mempengaruhi kejadian obesitas pada remaja. Jurnal Gizi Klinik Indonesia, 2015;11(4):179. https://doi.org/10.22146/ ijcn.22900

36. Giudicessi JR, Ackerman MJ. NIH Public Access. Bone, 2008;23(1):1-7.

37. Paley CA, Johnson MI. Abdominal Obesity and Metabolic Syndrome: Exercise As Medicine? BMC Sports Science, Medicine and Rehabilitation. 2018. https://doi.org/10.1186 /s13102-018-0097-1 PMid:29755739 PMCid:PMC5935926

38. Izawardy D, Taha AR, Astuti M, Achadi EL, Hardinsyah BAK, Kemenkes. Pedoman gizi seimbang. 2014.

39. Mulè G. Metabolic syndrome in hypertensive patients: An unholy alliance. World Journal of Cardiology, 2014;6(9):890. https://doi.org/10.4330/wjc.v6.i9.890 PMid:25276291 PMCid:PMC4176799

40. Haris S, Tambunan T. Hipertensi pada Sindrom Metabolik. Sari Pediatri, 2009;11(4). https://doi.org/10.14238/sp11.4. 2009.257-63

41. Pandit D, Chiplonkar S, Khadilkar A, Kinare A, Khadilkar V. Efficacy of a continuous metabolic syndrome score in Indian children for detecting subclinical atherosclerotic risk. International Journal of Obesity, 2011;35(10):1318-24. https://doi.org/10.1038/ijo.2011.138 PMid:21772245

42. Balci RS, Acikgöz AK, Göker P, Bozkir MG. The Relationship of Finger Length Ratios (2D:4D) with Quantitative, Verbal Talent and Anthropometric Parameters. International Journal of Morphology, 2018;36(1):310-8. https://doi.org/10.4067/s0717-95022018000100310

43. White M, Jarrett T, Komar C. Correlation between Digit Length Ratios and Risk Factors Associated with Metabolic Syndrome. J Metabolic Synd, 2017;6(1). https://doi.org/10.4172/2167-0943.1000221 
44. Park Y-M, Pereira R, Erickson C, Swibas T, York K, Pelt R. Estradiol Mediated Improvements in Adipose Tissue Insulin Sensitivity are Related to The Balance of Adipose Tissue Estrogen Receptor $\alpha$ and $\beta$ in Postmenopausal Women. PLOS ONE, 2017;12(5). https://doi.org/10.1007/s11886016-0755-4 PMid:27312935 PMCid:PMC4911377

45. Yıldız P, Yıldız M, Yıldırım AC, Gücenmez S, Dönderici Ö, Serter R, et al. The 2 nd to 4 th Digit Length Difference and Ratio as Predictors of Hyperandrogenism and Metabolic Syndrome in Females. Konuralp Tıp Dergisi, 2015;7(1):45-9. Available at: www.konuralptipdergi.duzce.edu.tr
46. Swami S, Buddhiraja V, Gupta R, Bansal S, Gaur N, Sharma D. Correlation between Second to Fourth Digit Ratio and Anthropometric Variables Indicative of Cardiovascular Disease. Journal of Morphological Sciences, 2019;36(1):2932. https://doi.org/10.1055/s-0039-1678712 